\title{
Nowe kierunki w nauczaniu i wychowaniu prezentowane w „Ruchu Pedagogicznym” w dwudziestoleciu międzywojennym
}

\begin{abstract}
Abstrakt
W artykule przedstawiono odniesienia do europejskich, czy światowych doświadczeń w obrębie pedagogiki nowego wychowania. Czyniono to najczęściej za pośrednictwem czasopism naukowych lub popularnonaukowych. Do jednego z nich należał „Ruch Pedagogiczny” redagowany przez Henryka Rowida, autora koncepcji szkoły pracy. Na jego łamach prezentowano aktualne poglądy takich pedagogów, jak: J. Deweya, G. Kerschensteinera, H. Parkhurst, Owidiusza J. Decroly'ego, Rudolfa Steinera i innych. Poprzez „Ruch Pedagogiczny” starano się zachęcać całe środowisko nauczycielskie do odejścia od tradycyjnych metod nauczania i wychowania (mających swoje oparcie w dziewiętnastowiecznym herbartyzmie) na rzecz nowatorstwa pedagogicznego.
\end{abstract}

Słowa kluczowe: nauczanie i wychowanie, europejskie i światowe nowatorstwo pedagogiczne.

\section{New Directions in Teaching and Education Presented in "Ruch Pedagogiczny" in the Interwar Period}

\begin{abstract}
The article presents references to European and world experiences in the field of pedagogy "New Education", which were most often presented through scientific or popular science journals. One of them was the "Ruch Pedagogiczny" (The Pedagogical Movement), edited by Henryk Rowid, the author of the concept of the "school of work". In this journal were published articles presenting pedagogical views of such
\end{abstract}

\footnotetext{
* Uniwersytet Pedagogiczny im. Komisji Edukacji Narodowej w Krakowie. Artykuł otrzymano: 21.01.2020; akceptacja: 27.05.2020.
} 
educators as John Dewey, Georg Kerschensteiner, Helen Parkhurst, Ovide J. Declory, Rudolf Steiner and others. The articles published in "The Pedagogical Movement" were aimed at encouraging teachers to abandon traditional teaching and education methods (based on the assumptions of Herbart's 19th century pedagogy) and to choose innovative pedagogical solutions.

Keywords: teaching and education, European and world pedagogical innovation.

W latach międzywojennych za pośrednictwem „Ruchu Pedagogicznego” próbowano połączyć polską myśl pedagogiczną z europejskimi oraz światowymi dokonaniami w tym zakresie (Eksperymenty pedagogiczne... 1963: 428). Pierwszy numer czasopisma ukazał się w 1912 r. i kierowany był do grona galicyjskich pedagogów i nauczycieli (Jarowiecki 1997: 10-12). Wspomniane czasopismo odegrało ważną rolę w propagowaniu pedagogiki polskiej za pośrednictwem dyskursu obejmującego zmiany zachodzące $w$ oświacie i wychowaniu. Wymieniony tutaj periodyk od początku poświęcony był sprawom wychowania, nauczania oraz organizacji szkolnictwa. Jednocześnie odbiorcom swoim dawał szansę dotarcia do szerokiej wiedzy na temat aktualnego nowatorstwa pedagogicznego czy dydaktycznego. Z czasopismem „Ruch Pedagogiczny” związanych było wielu polskich pedagogów i uczonych. Wśród nich wymienić należy: Wandę Bobkowską, Ludwika Chmaja, Marię Grzegorzewską, Jana Hulewicza, Józefę Joteyko, Bogdana Nawroczyńskiego, Helenę Radlińską i Stefana Szumana, Stanisława Tynca, Zenona Klemensiewicza i Floriana Znanieckiego.

W omawianym okresie „Ruch Pedagogiczny” znalazł się w grupie czasopism, do których sięgało liczne grono odbiorców. Jego nakład kształtował się na poziomie dwudziestu tysięcy egzemplarzy ${ }^{1}$. W latach 1912-1934 czasopismo miało swoją siedzibę przy ulicy Lelewela w Krakowie, po czym przeniesiono ją do Warszawy na ulicę Smulikowskiego (Wybrzeże Kościuszkowskie). Początkowo pismem kierował Henryk Rowid. Po przeprowadzeniu redakcji do Warszawy na jej czele stanęli - Halina Heftmanowa, Benedykt Kubski, Marian Odrzywolski, Albin Jakiel i inni. Większy wpływ wówczas na ogólny nurt czasopisma miał Zarząd Główny Związku Nauczycielstwa Polskiego oraz jego Wydział Pedagogiczny. W praktyce nieco inaczej postrzegano zagadnienia związane z rozwojem naszej czy światowej pedagogiki. Natomiast kiedy czasopismem kierował H. Rowid, przeważały w nim przede wszystkim treści bliskie nowemu wychowaniu i pedagogice eksperymentalnej. W tym czasie krakowski periodyk zyskał sobie miano liczącego się czasopisma pedagogicznego, stawiającego na nowoczesne metody nauczania i wychowania. Zagadnienia nowego wychowania starano się przedstawiać w bardzo szerokim ujęciu, zauważając w nich konteksty filozoficzne, socjologiczne, psychologiczne oraz

\footnotetext{
1 Jednym z podstawowych założeń pracy organizacyjnej było, aby „Ruch Pedagogiczny” dotarł do każdego nauczyciela, członka Związku Nauczycielstwa Polskiego.
} 
odniesienia do dziejów wychowania ${ }^{2}$. Z wielu artykułów potwierdzających taki stan wymienić należy: Przesłanki filozoficzne i psychologiczne podstawy pedagogiki współczesnej (Sekreta 1929); Szkice z socjologii wychowania (Znaniecki 1924); Teoria pedagogiczna psychologii indywidualnej (Chmaj 1930); Stanowisko Ewarysta Estkowskiego w dziejach pedagogiki narodowej (Rowid 1920). W odtwarzaniu dziejów naszej edukacji dostrzec można zauważalny sentyment H. Rowida do twórczości Jana Władysława Dawida. Zwłaszcza w pierwszych numerach „Ruchu Pedagogicznego” można było zapoznać się z większymi lub mniejszymi fragmenta$\mathrm{mi}$ jego dorobku${ }^{3}$.

Z wybranych do analizy tekstów wynika, że wydawnictwo „Ruch Pedagogiczny" przywiązywało istotną wagę do propagowania pedagogiki eksperymentalnej i nowych rozwiązań we współczesnym wychowaniu. Dużo miejsca poświęcano pedagogice „szkoły pracy”, prezentując jej amerykańską, skandynawską lub włoską odmianę. W każdym z wymienionych przykładów odnaleźć można było krytykę dawnej szkoły, tradycyjnej, biernej, skoncentrowanej na formalnym nauczaniu. Zgodnie z panującym w nich herbartyzmie nauczyciel musiał skupiać się na ściśle określonych treściach i sposobie ich opanowania. W swojej biernej postawie nie mógł pozwolić sobie na indywidualizację nauczania oraz wszechstronny rozwój ucznia, co w konsekwencji nie mogło dobrze służyć całemu procesowi nauczania i wychowania. 0 odmianach „szkół pracy” pisał przede wszystkim Henryk Rowid, prezentując przy okazji własne dokonania w tym zakresie. W międzynarodowym ruchu „szkół pracy” dostrzegał on dwa nurty. Jeden z nich koncentrować się miał na pracach ręcznych jako dominującym środku wychowania, zmierzającym do ukształtowania psychiki i osobowości ucznia. W tym przypadku niezwykle ważnym był sposób wprowadzenia wymienionych tutaj prac ręcznych. W założeniach tej teorii roboty ręczne urastały do roli odrębnego przedmiotu, pojawiającego się na różnych poziomach nauczania szkolnego. Jako przedmiot nauczania musiał doprowadzić do lepszego rozumienia realizowanych treści i zagadnień w obrębie wiedzy przyrodniczej, geograficznej i innej. W drugim z wymienionych tutaj nurtów prace ręczne stać się miały istotnym elementem szkoły aktywnej. W tym przypadku prace ręczne postrzegano jako wysiłek dydaktyczny (fizyczny względnie umysłowy) polegający na wykonaniu określonych zadań, stawianych uczniom przez szkołę.

Dla lepszego zobrazowania zjawisk zachodzących w międzynarodowym ruchu nowego wychowania wybrano poglądy Johna Deweya i Georga Kerschensteinera. Zwłaszcza poglądy J. Deweya, znanego amerykańskiego pedagoga (przedstawiciela pragmatyzmu), cieszyły się ogólnym zainteresowaniem zarówno w Stanach Zjednoczonych Ameryki Północnej, jak i Europie. Już wówczas w Polsce miały one wielu naśladowców. W kontekście prezentowanej teorii starano się zwrócić uwagę na

\footnotetext{
2 Po 1912 r. ukazały się w „Ruchu Pedagogicznym” np. Podstawy filozoficznej pedagogiki - B. F. Trentowskiego i Wychowanie kierowane i filozofia - J. M. Hoene-Wrońskiego.

3 Wzajemne relacje pomiędzy wymienionymi osobami nawiązały się w latach 1910-1913, wtedy kiedy J.W. Dawid przebywał w Krakowie.
} 
- społeczne funkcje wychowania, jego demokratyzację (w tym indywidualizację), ideały i zasady szkoły demokratycznej oraz pragmatyczną rolę umysłu w odniesieniu do pracy fizycznej. Na podstawie jego myśli dostrzegano ciekawą próbę dostosowania szkoły do potrzeb i wymogów współczesnego świata. Stworzony przez J. Deweya typ nowego wychowania miał być odpowiedzią na rodzący się radykalizm, zwłaszcza wśród amerykańskiego społeczeństwa. Nie bacząc na inne względy, jedynie w jednostce dostrzegał on potencjał zachodzących zmian, czyniąc ją w pełni odpowiedzialną za wybór własnej drogi życiowej. Od wychowania oczekiwał, że stworzy ono „nowego człowieka”, twórczego i aktywnego, mogącego sprostać różnego rodzaju wyzwaniom. Do prezentowanych tutaj poglądów nawiązali też w swoich wypowiedziach Józef Chałasiński (1927) i Ludwik Chmaj (1936/1937).

Poprzez „szkołę pracy” stworzoną przez G. Kerschensteinera starano się eksponować dążenia do kształtowania osobowości ucznia oraz rozwój jego sfery duchowej opartej na samodzielnym myśleniu i działaniu. Postanowiono sięgnąć do istoty tej szkoły poprzez zrozumienie jej propaństwowości w wychowaniu oraz użytecznego stosunku do otaczającej rzeczywistości. G. Kerschensteiner w państwie poszukiwał jednego z najważniejszych wytworów (organizmu) działalności społecznej, stojącego na straży zbiorowego porządku oraz doskonałości w kształtowaniu poszczególnych osobowości. Od państwa oczekiwał też dobra zewnętrznego (gwarancji), bez którego nie może dokonać się wewnętrzny rozwój jednostki. U podstaw tak rozumianej „szkoły pracy” znalazła się działalność rękodzielnicza i manualna. Zgodnie z przyjętymi w ten sposób założeniami przy każdej ze szkół początkowych powinno znaleźć się miejsce do wykonywania pracy ręcznej (warsztatu, ogrodu czy kuchni szkolnej), tak aby poprzez nią uczniowie mogli rozwijać swoje umiejętności oraz skłonności do samodzielnego i sumiennego wykonywania niezbędnych życiowych czynności (Baścik 1962).

Do swojej koncepcji określonej mianem „szkoły twórczej” zachęcał H. Rowid4 Miał nadzieje, że zostanie ona dobrze przyjęta przez szerokie grono nauczycieli i pedagogów. Zanim przedstawił ją w postaci ostatecznej, zapoznał się z podobnymi rozwiązaniami, zastosowanymi w szkołach europejskich: Niemiec, Austrii, Francji i Szwajcarii (Rowid 1925). W głoszonej przez siebie teorii wypowiadał się na temat koncepcji „nowego człowieka” ukierunkowanego na nową cywilizację, opartą na zdrowej moralności, świadomej odpowiedzialności i aktywnej pracy umysłowej (własnej). W opracowanych przez siebie rozwiązaniach pedagogicznych opowiedział się za dążeniem do realizacji własnych potrzeb życiowych. Za właściwą metodę w ich realizacji uznał rozwój wrodzonych skłonności, opartych na zainteresowaniach i funkcjonalnej psychice. W jego szkole dzieci miały być aktywne, a szeroką wiedzę zdobywać poprzez wzmożoną pracę własną. Zgodnie z ogólnie przyjętą zasadą nowego wychowania nauczyciel miał jedynie kierować indywidualną pracą ucznia i pomagać dziecku w samodzielnym zdobywaniu wiedzy. Nie

\footnotetext{
4 „Szkoła twórcza” należało do szerszego nurtu nazywanego „Szkołami pracy”.
} 
oznaczało to jego bierności czy słabości w przygotowaniu do realizowanych zadań. Wręcz przeciwnie, powinien znacznie wykraczać poza ściśle przyjęte ramy zaangażowania w proces nauczania oraz dążyć do samokształcenia. Mając świadomość doskonalenia nauczycieli, H. Rowid przygotował szereg wskazań metodycznych oraz opracował wzory i szkice lekcji dla osób chcących wprowadzać innowacje pedagogiczne. Oto jeden z przykładów:

\section{Lekcja o kocie}

A. Przeżycia dzieci i obserwacje - Dzieci opowiadają swobodnie, po kolei o swoich kotkach w domu lub o kotkach u sąsiadów (...).

B. Przeróbka psychiczna - Dzieci porządkują pod kierunkiem nauczyciela zgromadzony materiał w logiczną całość w ten sposób, by powstało żywe i barwne opowiadanie o kocie (...).

C. Wyrażenia - Rozdajemy dzieciom glinę i polecamy ulepić kota, przy czym pobudzamy je do pewnej pomysłowości (...).

Po takim przygotowaniu następuje czytanie z zastosowaniem ruchomego alfabetu i pisanie (...). Lekcja w tym duchu prowadzona pobudzi dzieci do pracy produkcyjnej, do działania, będzie dla nich prawdziwą rozkoszą, bo i dziecko, podobnie jak człowiek dojrzały, doznaje zadowolenia, uczuć przyjemnych w chwili działania, w chwili tworzenia (Rowid 1921: 41).

Nauczyciele zainspirowani tymi wskazówkami opracowali szereg własnych lekcji. W większości prezentowali je na pokazowych lekcjach szkolnych lub na kursach dla nauczycieli. Przy czym należy podkreślić, że obejmowały one zarówno zajęcia szkolne prowadzone zarówno w oddziałach początkowych, jak i starszych. W jednej z szóstych klas krakowskiej szkoły powszechnej odbyła się lekcja z języka polskiego na temat - „Tryb rozkazujący”. Podczas niej uczniowie pracowali zgodnie z ustalonym wcześniej porządkiem, tj. obejmującym: podbudowę; obserwację i gromadzenie materiału; analizę i uogólnienia oraz samodzielne zastosowania przykładów wybranych z życia codziennego i literatury. W celu zobrazowania wybranego tematu wykorzystano literaturę Kazimierza Przerwy-Tetmajera (wiersz Pozdrowienie) i Adama Asnyka (wiersz Echo kołyski). Na koniec uczniowie musieli sporządzić własne notatki i zapisać je w swoich zeszytach do gramatyki. Obejmowały one co najmniej 15 przykładów odnoszących się do trybu rozkazującego (Majewiczówna 1926).

$\mathrm{Z}$ innych koncepcji nauczania i wychowania przedstawianych na łamach „Ruchu Pedagogicznego” wymienić należy pedagogikę: Owidiusza J. Decroly’ego, Rudolfa Steinera i Heleny Parkhurst („plan daltoński”) (Majewiczówna 1926). Jako jedną z metod doskonalących nauczanie i wychowanie wskazano pedagogikę 0. Decroly’ego. Cieszyła się ona wówczas w Polsce powszechnym zainteresowaniem. Przedstawiano ją w odniesieniu do jednolitego systemu pedagogicznego, zmierzającego do wychowania człowieka (dziecka) czynnego, twórczego, posiadającego pełną świadomość swoich sił i możliwości (Wróbel 1962). W obrębie wy- 
chowania moralnego zwrócono uwagę na przygotowanie dziecka do życia poprzez życie i zorganizowane mu środowisko tak, aby znalazło w nim bodźce do samodzielnego działania. W nauczaniu główną uwagę przywiązywano do tego, co pożyteczne, a nie do tego, co piękne i doskonałe. Poprzez pedagogikę Decroly'ego próbowano rozwiązać problem indywidualizacji zajęć i ich właściwy układ, sprzyjający rozwojowi zainteresowań dziecka (Majewiczówna 1926).

Wśród ciekawszych koncepcji nauczania i wychowania znalazła się pedagogika Rudolfa Steinera. W jego poglądach zwrócono uwagę na antropozoficzne postrzeganie człowieka (ciała, duszy i ducha) oraz troistość życia duchowego, prawnego i gospodarczego. Zachwycano się dużym znaczeniem eurytmii w programie nauczania szkoły steinerowskiej. Według Steinera prowadzić miała ona do realizacji celów wyższych, do których zaliczał człowieczeństwo i duchowość. W eurytmii dostrzegano sztukę wyrażania własnej osobowości poprzez formowanie określonych ruchów ciała. Wraz z mową i śpiewem regulowała oddech, a ręce i ramiona starały się ukazać treść prezentowanego wyrazu. W pedagogice steinerowskiej (zwanej też często waldorfską) obok działań artystycznych, do których zaliczono wspomnianą eurytmię, ważną rolę odgrywały działy (piony): akademicki i zajęć praktycznych. Te ostatnie przybierały postaci prac ręcznych, pracowni, warsztatu lub pielęgnowania ogrodu. W antropozoficznej pedagogice R. Steinera nie bez znaczenia była rola nauczyciela, do której przygotowywano w sposób szczególny .

Na ukształtowanie dziecka, zdaniem Steinera, wielki wpływ ma temperament nauczyciela. Niepohamowany temperament niezmierną szkodę może przynieść dziecku na całe życie. Nauczyciel, który poddaje się swemu temperamentowi cholerycznemu, budzi u dziecka obawy, które mogą być przemijające, ale mogą wpłynąć też na fizyczną i psychiczną organizację dziecka i wywołać podświadomy nastrój przygnębienia. Wybuchy temperamentu cholerycznego przechodzą do duszy dziecka, przeszczepiają się w ciało jego, aby później, gdy będzie już człowiekiem dojrzałym, ujawnić się (Bandura 1932).

W szkole pracującej pedagogiką R. Steinera zalecano, aby do 14. roku życia dziecko miało tego samego wychowawcę (nauczyciela), który powinien nauczać wszystkich przedmiotów (tamże).

Do pracy metodą Heleny Parkhurst zachęcał H. Rowid, chociaż system ten miał i innych zwolenników. W artykule zatytułowanym System Daltoński (Rowid 1924) starał się przybliżyć ogólne zasady tego nowego kierunku, dostrzegając w nim swobodny ruch i dążenie do samodzielnej pracy. Do szerszego zainteresowania tym systemem doszło za sprawą pogłębionego studium pt. Le plan Dalton, opublikowanego przez francuskiego pedagoga M. Garde. Autor wspomnianego studium przekazuje w nim swoje spostrzeżenia z wizyty w wyższej szkole elementarnej dla dziewcząt w angielskim Cambridge, którą nazywano Central School (Rowid 1924). Całość 
ogłoszona została w czasopiśmie „Revue Pédagogique”. Wydaje się, że to właśnie ten artykuł skłonił H. Rowida do upowszechnienia wspomnianej metody wśród polskich pedagogów i nauczycieli szkół powszechnych. W Polsce idea planu daltońskiego jako metody aktywnego nauczania znalazła także swoich naśladowców dzięki relacjom przygotowanym przez Jadwigę Młodowską. W jednej z nich autorka przedstawiła swoje wrażenia z podróży dydaktycznej po Anglii (Młodowska 1926). W sprawozdaniach przygotowanych przez Młodowską znalazły się opisy szkół angielskich, gdzie „system daltoński” był obecny od kilku lat, zarówno w szkołach niższych, jak i średnich. Zgodnie z tym planem starano się realizować trzy podstawowe zasady - swobodne działanie, samodzielną (zindywidualizowaną) pracę i współdziałanie z grupą. Przy czym wprowadzony w Anglii system różnił się nieco od tego, znanego ze szkół amerykańskich. Jedną z różnic było to, że w programie (tygodniowym) szkół angielskich część lekcji z danego przedmiotu nadal realizowana była według poprzedniego planu. Ograniczono jedynie dla nich liczbę godzin. Młodowska, zainspirowana angielskimi przykładem, wystąpiła do Ministerstwa Wyznań Religijnych i Oświecenia Publicznego o wyrażenie zgody na wprowadzenie podobnych rozwiązań w państwowych kursach, organizowanych przy żeńskim Seminarium Nauczycielskim w Chełmie (Doroszewski 2003). Po uzyskaniu aprobaty system ten ruszył najpierw w odniesieniu do ośmiu przedmiotów, czyli: języka polskiego, historii, geografii, matematyki, fizyki (względnie chemii), biologii, robót ręcznych i rysunku, a następnie objęty został innymi zajęciami (Młodowska 1926). Warto w tym miejscu podkreślić, że w podobnym czasie o wspomnianej metodzie wypowiadała się też Stanisława Niemcówna. Na temat nauczania geografii z wykorzystaniem wspomnianego planu pisała w ten sposób:

Dlatego to nigdzie tak właśnie, jak w zakresie nauki o Polsce współczesnej nie możemy stosować prawd i praw systemu daltońskiego. Tylko, kiedy uprzednio głównie odwoływaliśmy się do map, obrazków, literatury geograficznej, to teraz główny nacisk położymy na bezpośrednie przeżycia młodzieży, na ich doświadczenia zaczerpnięte z życia codziennego oraz na wyniki obserwacji, robionych przez młodzież w czasie dłuższych po Polsce wędrówek (Niemcówna 1928: 271).

Po zamieszczeniu artykułu J. Młodowskiej o „planie daltońskim” (często określanym laboratoryjną metodą nauczania) pojawiło się kilka innych publikacji. W każdej z nich starano się przedstawić postać H. Parkhurst i próbę wprowadzenia tej metody w jednoklasowej szkole w mieście Dalton. Zaprezentowano też drogę, jaką przeszła H. Parkhurst w dojściu do własnych metod nauczania. Nie omieszkano wspomnieć o roli M. Montessori, pod kierunkiem której przyszła twórczyni metody laboratoryjnej odbyła studia z psychologii i pedagogiki. We Włoszech młoda Amerykanka znalazła się w gronie bliskich asystentek Montessori i miała możliwość zapoznania się z wprowadzanymi przez nią metodami pracy wycho- 
wawczej. Jednocześnie na ziemi włoskiej uzyskała stopień doktora nauk pedagogicznych, co jedynie wzmocniło jej dążenia do opracowania nowoczesnego nauczania ${ }^{5}$. Przechodząc już do metody H. Parkhurst, stwierdzić należy, że chciała ona skłonić dzieci do pracy twórczej. Odbyć miało się to poprzez podział izby szkolnej na samodzielne oddziały pracy naukowej, wyposażone w najlepsze pomoce dydaktyczne, materiały naukowe oraz literaturę (książki). Prawie w każdym z zamieszczonych artykułów spotkać można było gruntowną charakterystykę systemu daltońskiego. Omawiano go za pomocą głównych założeń teoretycznych i filozoficznych oraz poprzez wnikliwą charakterystykę koncepcji opartej na zasadach pracy indywidualnej i laboratoryjnej. Zgodnie z nią wspomniany system uwzględniać miał zainteresowania uczniów i tempo ich indywidualnej pracy. Nauczyciel po raz pierwszy mógł przekonać się o tym, że przy realizacji podstawowych zadań dydaktycznych nie musi dzielić uczniów na klasy. W zamian miał możliwość tworzenia klaso-pracowni będących czymś w rodzaju laboratoriów dla poszczególnych przedmiotów. Przy czym opisywana metoda czyniła z nauczyciela swego rodzaju specjalistę odpowiedzialnego za przygotowanie rocznych, miesięcznych lub tygodniowych planów nauczania (Rowid 1927; Taubenszlag 1929a).

Nieco inaczej na temat („planu daltońskiego”) wypowiedział się Rudolf Taubenszlag. Według niego o niedoskonałości tego planu świadczyć mogły jego założenia teoretyczne i trudności w przy ich realizacji. W swoich uwagach podnosił zarzut narzucania uczniom ściśle określonych celów i programu zadań. Z innych niedoskonałości wymieniał duży koszt wyposażenia klas, skomplikowany schemat przydziału zadań oraz trudności w pozyskaniu odpowiedniej kadry nauczycielskiej. Poważnym problemem dla niego były obawy natury pedagogicznej, w szczególności wychowawczej, co znacznie obniżało wartość wprowadzonego eksperymentu. Zamieszczona polemika nie przeszkodziła mu w opublikowaniu wzorów kart indywidualnych, laboratoryjnych i klasowych, które mogły stanowić cenną wskazówkę dla nauczycieli chcących pracować tą metodą (Taubenszlag 1929b).

W latach 1918-1934 „Ruch Pedagogiczny” odegrał istotną rolę w propagowaniu pedagogiki eksperymentalnej i nowych prądów w wychowaniu. Opublikowano wiele artykułów, w których podnoszono rolę i znaczenie współczesnej pedagogiki. Nie sposób wymienić wszystkich, chociaż warto w tym miejscu nawiązać do kilku o szczególnym znaczeniu metodyczno-dydaktycznym. Z ciekawszych wymienić należy artykuły: A. Szycówny o nowych prądach w nauczaniu początkowym, H. Orsza-Radlińskiej o metodyce nauczania historii. Z drugiej strony - o edukacji progresywnej i metodach aktywnych mogliśmy dowiedzieć w oparciu o poglądy

\footnotetext{
5 Metoda planu daltońskiego zawdzięcza swój rozgłos w Europie dzięki zbiegowi okoliczności. Głównie za sprawą wizytacji jednej najbardziej znanej angielskiej kierowniczce zakładu wychowawczego w Londynie, która po zwiedzeniu szkoły daltońskiej ogłosiła w znanym angielskim czasopiśmie „Times” entuzjastyczny artykuł o pracy Heleny Parkhurst. Następnie na fali popularności zostaje wprowadzony system daltoński w jednej ze szkół londyńskich. W tym czasie powstaje też specjalne stowarzyszenie naukowe „The Dalton Association”, a system upowszechnia się w wielu krajach w Europie i na świecie (także w Rosji i Japonii).
} 
może nieco mniej znanej osoby, szwajcarskiego pedagoga Adolfa Ferrière. Jako młody człowiek miał możliwość uczestniczenia w ciekawym międzynarodowym projekcie nowoczesnej szkoły, modelującej własny proces dydaktyczno-wychowawczy.

Godny podkreślenia był fakt, że „Ruch Pedagogiczny” starał się popierać praktyczne formy służące nowatorstwu pedagogicznemu. Czasopismo zachęcało do prezentowania na swoich stronach wszelkiego rodzaju inicjatyw zmierzających do podnoszenia jakości kształcenia. Już we wrześniu 1918 r. informowano o wakacyjnym kursie nauczycielskim „szkoły pracy”, który zorganizowano w szkole wydziałowej im. św. Jana Kantego w Krakowie. Wzięło w nim udział ponad trzydziestu nauczycieli z byłej Galicji i Królestwa Polskiego. W programie kursu znalazły się wykłady teoretyczne, seminaria, zajęcia praktyczne oraz lekcje wzorowe przeprowadzone w klasie pierwszej. Na temat teoretycznych podstaw „szkoły pracy" wypowiedział się H. Rowid. Natomiast zajęcia praktyczne skupiły się na rysunku metodycznym, modelowaniu, wycinaniu i drobnym slojdzie. Wzorcowe lekcje metodą "szkoły pracy” przeprowadziła J. Bladowska (Wakacyjny kurs... 1918). Warto zauważyć, że do organizacji podobnych kursów doszło również w latach następnych i powiązano je z działalnością Państwowych Kursów Nauczycielskich w Krakowie. Miały one pełne wsparcie ze strony krakowskiego Kuratorium Okręgu Szkolnego.

Metody dydaktyczno-wychowawcze stosowane w polskich szkołach próbowano zmienić różnymi sposobami. Jednym z nich była Ankieta $w$ sprawie urzeczywistnienia zasad szkoły twórczej w szkole polskiej, gdzie znalazły się cztery zasadnicze pytania co do jej istoty. Za pomocą ankiety starano się ustalić stan wiedzy na temat szkoły twórczej i osobisty do niej stosunek. Sondażowe badania miały na celu sprawdzenie, czy nauczyciele są już gotowi do podejmowania pracy tymi metodami. Nauczycieli zachęcano do prezentacji własnych doświadczeń i wzajemnych kontaktów, w tym międzynarodowych. Za przykład podano jedną z ciekawszych wymian, do której doszło w sierpniu 1928 r. w Krakowie. Gościła tutaj kilkuosobowa delegacja nauczycieli szkół powszechnych i średnich. Wraz z nimi do stołecznego miasta Krakowa dotarła reprezentacja profesorów uniwersytetu w Cambridge oraz zespół specjalistów z różnych dziedzin wiedzy i życia. Przybyłym gościom zaprezentowano dokonania edukacji polskiej, pokazując im szkoły w Warszawie, Wejherowie, Krakowie i Zakopanem. Głównym punktem wizyty była jednak konferencja zorganizowana z myślą o nauczycielach szkół średnich i powszechnych, na której rozmawiano na temat szczegółowego układu nauki według systemu daltońskiego (Majewiczówna 1928). Wspomnianej wymianie patronowało Ministerstwo Wyznań Religijnych i Oświecenia Publicznego, co dodatkowo podkreślało rangę i znaczenie tego wydarzenia.

Opisywana powyżej aktywność prowadzona przez czasopismo na rzecz najnowszych osiągnieć w pedagogice polskiej i światowej osłabła nieco w drugiej połowie lat trzydziestych. Nie poprawiły nawet tego przygotowania do IV Kongresu 
Pedagogicznego (Postępowa myśl... 1972). Przyczyn zaistniałej sytuacji mogło być wiele. Pismo borykało się z różnymi trudnościami, między innymi z zachowaniem ciągłości nakładu. Od września 1937 do marca 1938 nie przygotowano do druku ani jednego numeru. Zmienił się też nieco profil wydawanego czasopisma, w efekcie czego w centrum zainteresowań znalazły się przede wszystkim wyzwania stojące przed polską szkołą, a nie międzynarodowe rozwiązania edukacyjne. Znacznie mniej miejsca poświęcano europejskim czy światowym dokonaniom w pedagogice eksperymentalnej i nowoczesnym metodom nauczania. $Z$ tego okresu na szczególną uwagę zasługuje właściwie tylko jeden artykuł, autorstwa Ludwika Chmaja, pt. Filozofia wychowania Johna Deweya (Chmaj 1936/1937). W obszernym ujęciu, autor ukazał w nim wpływ J. Deweya na współczesną myśl pedagogiczną. Chmaj zaprezentował Deweya jako jednego z najwybitniejszych pedagogów (filozofów-pragmatystów), patrzącego na rozwój dziecka poprzez pryzmat jego psychiki, przeżyć, czynnych zainteresowań i bezpośrednich doświadczeń. Według niego we współczesnej szkole powinniśmy dostrzegać instytucję żywą, będącą dla dziecka źródłem radości i odkrywania własnych możliwości. Od szkoły wymagał przystosowania się do współczesnych potrzeb życia społecznego, a od wychowania twórczego i konstrukcyjnego demokratyzmu. Wspomniany artykuł miał dużą wartość poznawczą, ponieważ przypominał pedagogikę J. Deweya w odniesieniu do czynnych zainteresowań dziecka, jego rozwoju społecznego i aktywności w kontekście upadającej demokracji szkoły polskiej (tamże).

\section{Bibliografia}

Bandura L. (1932) Pedagogika antropozoficzna Steinera (dokończenie), „Ruch Pedagogiczny", nr 9, s. 236.

Baścik S. (1962) Szkoła pracy G. Kerschensteinera w: Studia nad pedagogikq XX wieku, wstęp i redakcja W. Okoń, B. Suchodolski, Warszawa, Państwowe Zakłady Wydawnictw Szkolnych, s. 60-79.

Bieńkowski W. (1990) Rowid Henryk, Polski Słownik Biograficzny, Wrocław-Warszawa-Kraków, Zakład Narodowy im. Ossolińskich, Wydawnictwo Polskiej Akademii Nauk, z. 133, s. 338-341.

Chałasiński J. Konferencja w sprawie systemu daltońskiego (1927), Dewey jako pedagog demokracji, „Ruch Pedagogiczny”, nr 1, s. 12-21.

Chmaj L. (1930) Teoria pedagogiczna psychologii indywidualnej, „Ruch Pedagogiczny”, nr 5, s. 201-216.

Chmaj L. (1936/1937) Filozofia wychowania Johna Deweya, „Ruch Pedagogiczny”, nr 4/5, s. 219-144. 
Danecki Z. (1930) Podstawy kierunku wychowania Decroly'ego a problem reformy wychowania w Polsce, „Ruch Pedagogiczny”, nr 4, s. 145-149.

Doroszewski J. (2003) Jadwiga Młodowska - wybitny nauczyciel Polski międzywojennej, „Przegląd Historyczno-Oświatowy”, nr 1-2, s.75-85.

Eksperymenty pedagogiczne $w$ Polsce w latach 1900-1939 (1963), materiały zebrali W. Dzierzbicka i S. Dobrowolski, Wrocław, Zakład Naukowy im. Ossolińskich.

Jarowiecki J. (1997) Studia nad prasq polskq XIX i XX wieku, Kraków, Wydawnictwo Naukowe Wyższej Szkoły Pedagogicznej w Krakowie.

Majewiczówna M. (1926) Szkic lekcji języka polskiego w duchu szkoły twórczej, „Ruch Pedagogiczny", nr 8, s. 240-245.

Majewiczówna M. (1928) Konferencja w sprawie systemu daltońskiego, „Ruch Pedagogiczny", nr 7, s. 215-217.

Młodowska J. (1926), System Daltoński. Wrażenia z wycieczki do Anglii i doświadczenia z własnej szkoły, „Ruch Pedagogiczny”, nr 9, s. 257-265.

Niemcówna S. (1928) Geografia w daltońskim systemie pracy szkolnej, Ruch Pedagogiczny", nr 9, s. 271.

Postępowa myśl oświatowa w Polsce w latach 1918-1939 (1972), wstęp i opracowanie Bronisław Ługowski, Feliks Araszkiewicz, Wrocław-Warszawa-Kraków-Gdańsk, Zakład Narodowy im. Ossolińskich Wydawnictwo Polskiej Akademii Nauk, s. XXXVIXXXVII.

Rowid H. (1920) Stanowisko Ewarysta Estkowskiego w dziejach pedagogiki narodowej, „Ruch Pedagogiczny”, nr 9-10, s. 165-177.

Rowid H. (1921) Idea szkoły pracy w zastosowaniu praktycznym, „Ruch Pedagogiczny", nr 1-3, s. 41.

Rowid H. (1924) System Daltoński, „Ruch Pedagogiczny”, nr 7-8, s. 220-227.

Rowid H. (1925) Życie w szkole twórczej. Wrażenia i refleksje z podróży pedagogicznej, „Ruch Pedagogiczny”, nr 4, s. 113-118.

Rowid H. (1927) System Daltoński w szkole powszechnej, „Ruch Pedagogiczny”, nr 2, s. 44-47.

Sekreta J. (1929) Przesłanki filozoficzne i psychologiczne podstawy pedagogiki wspótczesnej, „Ruch Pedagogiczny”, nr 7-9, s. 206-223. 
Wakacyjny kurs „Szkoły pracy” w Krakowie, „Ruch Pedagogiczny” 1918, nr 7, s. 166.

Wróbel T. (1962) Owidiusz Decroly - przedstawiciel naturalizmu w pedagogice w: Studia nad pedagogikq XX wieku, wstęp i redakcja W. Okoń, B. Suchodolski, Warszawa, Państwowe Zakłady Wydawnictw Szkolnych, s. 45-59.

Taubenszlag R. (1929a) System Daltoński, „Ruch Pedagogiczny”, nr 2, s. 40-50.

Taubenszlag R (1929b) System Daltoński, „Ruch Pedagogiczny, nr 4, s. 105-115.

Znaniecki F. (1924) Szkice z socjologii wychowania, „Ruch Pedagogiczny”, nr 7-8, s. $145-159$. 